\title{
(Neo)mythological Elements \\ in the Modern Russian Prose \\ (through the Example of "Surgeon" \\ by Marina Stepnova)
}

\author{
Jasmina Vojvodić* \\ University of Zagreb \\ 3 Ivan Lucic Str., Zagreb, 10000, Croatia
}

Received 10.01.2017, received in revised form 24.02.2017, accepted 14.04.2017

\begin{abstract}
The article deals with the method of neomythologization in the novel "Surgeon" by Marina Stepnova. Taking into account that neomythologizm is an important component in the modern socio-cultural ecumene and quite a complex concept, in the novel we analyze one segment of it - the creation and killing of "God" and divine position. The protagonist of the novel, a plastic surgeon Khripunov living in the 20th century, like Hassan-ibn-Sabbah, a monk of the 11th century, is a kind of "God" that in the text is shown through the light of narcissism and the desire to gain the power. At the structural level, the demiurge is the author per se who organizes the narratological whole of the two-side text.
\end{abstract}

Keywords: neomythologism, «Death of God», narcissism, «Surgeon», Stepnova.

The text is written under the project Neomythologism in the Culture of the 20th and 21st Centuries made by Croatian Scientific Fund (Neomyth, HRZZ, 6077).

DOI: 10.17516/1997-1370-0083.

Research area: philology.

The studies of (neo)mythological structures in the Russian literature of the modern time lead to the fact the "mythological believes do not fade, but become transformed being adapted in a new cultural and historical situation" (Akhmetova, 2010: 10). Could it then be said that almost every literary work is a myth? Zara Mints wrote that "the art on the whole as the most perfect insight into the existence mystery and as its transformation per se is considered the equivalent of the myth, i.e. of its nature and cultural function" (Mints,
2004: 61). If that is so, the question is how should we distinguish the myth out of the literature and find out how the myth enters the literature which obviously uses mythological elements, plays with mythological structures and motives or speaks ironically about mythological concepts?

Neomythologism is a notion connected with the 20th and 21st century cultures. Zara Mints said about the neomythologism of the Russian symbolists whose addressing to the myth seemed to be a way out of the "cognition crisis", while in

(c) Siberian Federal University. All rights reserved

* Corresponding author E-mail address: jasmina.vojvodic@ffzg.hr 
the Dictionary of 20th Century Culture "Rudnev extended this term within the time pointing out that "neomythological consciousness is one of the main vectors of the cultural mentality in the 20th century from symbolism till post-modernism" (Rudnev, 1999: 184). It is hard to say how far the mythological consciousness terminated by post-modernism since the modern culture is largely marked by the crisis of the naturalscientific knowledge and in many ways increases the interest towards the irrationality and unconsciousness representing an ideal ground for a new type of mythologization. The post-modern atomism of the knowledge, pluralism of values, rhizome, hesitations in logocentrism and etc. turn the human towards mythological thinking. Being unable to explain the environment, the man is searching for an anchor, and in the literary text, in its atoms and equalization of the values and styles in a "anything goes"-based manner he is searching for a heaven-sent Ariadne's clew.

The notion of myth widens and that is why Rudnev, among other things, points out that within the modern context "it is particularly significant that the role of myth "lightening" the plot is played not only the mythology in its narrow sense, but also historical traditions, popular mythology, historical and cultural reality of the prior decades, well-known and unknown literary texts of the past" (Rudnev, 1999: 185). The fact that $t$ eh text is full of allusions, reminiscences, and that it even "starts assimilating the myth in its structure" (Rudnev, 1999: 185) characterizes both modernist and post-modernist literatures. The myth of contemporary times "wears antiscientific clothes" (Neklyudov, 2000), plays with the mass culture cliches or else the wirters create their own mythology. Meletinskiy points out that the 20th century is based on demythologization, but since this process is incomplete it occasionally is interrupted by the process of re-mythologization (Meletinskii, 2005). Almost the whole 20th century can be describes as crisis, whether there are the beginning or the end, and "addressing to the myth becomes vital in hard historical times which drastically change the world and human image when it comes to new criteria of the existence" (Kovtun, 2013: 5). In this context, the art and literature in particular bring up substantive and fundamental problems, as well as a demand to find the answers. Neomythologization of the modern literature involves that game with the fundamental questions and it enters into a dialog with an ancient myth and mythological structures of the modernistic times.

The text of modernism have "built the worlds" for many times and relied on their ability to produce new worlds, embodied what the life would be. They even believed in the power of myths (Solar, 2000). The myth as a clue for the fundamental nature of the historical reality, contemporaneity and art, as it is described by Mints, resembled "the deepest way for the world comprehension and life transformation" for the symbolists (Mints, 2004: 62). To become a myth is a desirable future for them. "Bright and mind blowing metaphors, virtual projects in philosophy by Nietzsche, Vl. Soloviev, Fedorov, Tsiolkovsky, Vernandsky, S. Bulgakov and others required an immediate practice" (Romanova and Ivantsov, 2016). The modernist believed in the aim and universalism as yet, and thus "he accepted the ideas of new values optimistically" (Romanova and Ivantsov, 2016). The post-modernist, in turn, doubting any values and highlighting his slogan "everything is useful", defames them. Neomythologization of the modern literature, in that way, together includes estrangement from the myth, speaking ironically by its negative opinion; return to the mythological structures and pseudo-attempt to create a new world.

In this work we will try to show the way how the modern novel plays neomythologism through 
the example of "Surgeon" by a contemporary Russian writer Marina Stepnova (2005)1.

The plot develops in two scenes. The first of them shows the life of Arkady Khripunov, a plastic surgeon, and the other one is dedicated to Hassan-ibn-Sabbah, a monk. The fates of these characters interlinks despite that they are separated by the time and space. Khripunov lives in the Soviet Russia in the second half of the 20th century, whereas ibn-Sabbah - in the 11th century, in Persia of the times. Generally, as it has been fairly noted by Nikolina, "the time structure in the modern prosaic literary works is characterized by the interaction and intersection of different temporal layers" (Nikolina, 2009: 269). Khripunov's fate is deployed steadily till his successful career of a prominent plastic surgeon, when he being above all the rest, ordinary people, has become a God:

«Над столом, затянутые в зелено-лиловую форму, безликие, безмолвные, безотказные, они всего лишь нейроны и рецепторы одного единственного Бога - безжалостного и всемогущего. Имя которому Хрипунов» (159).

Khripunov is a surgeon, and the surgery, according to his words, "is the only opportunity for the doctor not to damage, but to create". It is worth mentioning that early in the beginning of the novel, from its epigraph, the reader learns that Khripunov want to become the God, i.e. his life flows to make his aim come true:

«Хрипунову плевать было на людей. Хрипунов хотел стать Богом. Что нужно человеку, решившему стать Богом? Имя. Промысел. Деяние. Жертва. Все это было у Хрипунова. И он стал Богом. Он. Им Стал».

"Name", “craft", "act" and "victim" represent separate chapters of the novel approving the life's journey and value of the surgeon within the structure.

Khripunov was named as Arkady that can be linked not only to the ancient Greek tradition of this name - the son of Zeus and his beloved Callista, but to the name of Gaidar, the Soviet Russian writer of children's stories. In the ancient Greek mythology this name is quite common as well as that high and low ("pastoralist") status of Arcadius per se: Zeus changed Callista into a she-bear to safe her from Hera's (his wife) revenge. Once being on a hunt, Arcadius almost killed this she-bear, not knowing that it was his mother. To pull his son from killing the mother, Zeus changed them both into the Great and Little Bears (Zamarovský, 1989). The constellation is important, since following the shape of the Bear, one can find the Pole Star. The surgeon Arkady Khripunov is some kind of "pole star", a star of high, "heaven" principle, i.e. his name already involves that mythological tradition. On the other hand, the name is closely connected with Gaidar - that was his mother's idea when choosing her son's name. Being pregnant, his mother was reading the story by A. Gaidar titled "Golubaya Chashka" (eng. - "Blue Cup"). To remind, it is referred to the Soviet Russian writer of children's stories, whose name and works played a crucial role in children's education. The surname, Gaidar, the writer Arkady Petrovich Golikov chose by himself. In Mongolian Gaidar means "a rider racing in front" (Baiburin, 2016).

S. Mikhalkov wrote about him the same:

$$
\begin{aligned}
& \text { «Любимых детских книг твореи, } \\
& \text { Иверный друг ребят, } \\
& \text { Он жил, как должен жить боеи, } \\
& \text { И умер как солдат...» (Baiburin, 2016). }
\end{aligned}
$$

The child's name in "Surgeon" could be an ordinary one, such as "Vanyusha", "ordinary Ivan", as his father wanted it to be, but the mother 
chose that very name - Arkady. It is interesting that the novel doesn't say about the parents' names, they are called simply according to their function "Khripunov's father" and "Khripunov's mother", as of their performance is limited only by their child's upbringing:

«Мальчик - сказал за правым плечом утробнылй незнакомылй голос, и хрипуновская мама вдруг увидела потрепанную детскую книжку с черными чершавыми буквами на обложке - «Аркадий Гайдар» - и тут все затянуло легчайшей, нежной, невесомой мутью, боль отхльнула, и на смену ей пришло лиць - безмятежное, странное и такое огромное - во весь потолок, во весь мир, во все небо - что хрипуновская мама даже не поняла-мужское оно или женское» (21).

Having become a famous doctor, Arkady Khripunov changed the appearance of people, interfering in that way into the creation. The end of his life is shown in the novel's conclusion and on the top of his working activity. It represents an ironic game in a concept of the God's Death, since the Good Angel who had brought a newborn Khripunov for 39 years ago, came into the room and announced by the phone that the Surgeon-God had been dead.

Separately, at first glance, from Khripunov's fate, we can track the history of Hassan-ibnSabbah. It is worth noting that ibn-Sabbah, or Hasan-i-Sabbah, was a real person, Islam man of the 11th century. He lived from 1056 till 1124, in Alamut, Western Persia, and was the founder of the Assassin's political sect, who with the follower killed enemies (Šentija 1977). According to the sources, ibn-Sabbah lead a radical spirit movement of Islamism. In the early Islam, both Islamic theologists and historians from the West rejected and consider him as a sectarian, and the word "assassin" was equal to the word "murderer".
Marina Stepnova, definitely, used the historical evidences when creating this character, since much of the information from his private and political life can be found in encyclopedias. The historical, which is often lifted to higher levels and mythologized, i.e. becomes a truth of the highest order, is outplayed in Stepnova's novel by marking the position of ibn-Sabbah who like his "competitor" from the 20th century represents some sort of "God". Ibn-Sabbah determined the fates of other people and decided who would live and who must die; he was rich and "almighty as the God" (168). His ordinary, contrary to which he and his home were chosen by the God, is described ironically:

\section{«...Когда луч этот начинал пульсировать} и шептать ибн Саббаху в уши высоким нездешним голосом, Хасан ибн Саббах вставал и шел убивать» (37).

Ibn-Sabbah was "the God on the Earth", i.e. "Allah's governor". He passed the temptation, the "nine steps of Bahirah, those none steps which separate an ordinary people from the eternity". People of Alamut believed ibn-Sabbah "as have never ever believed any other God".

Both character in this novel, Khripunov and ibn-Sabbah play in God and feel themselves as being chosen to kill/create following their desires: ibn-Sabbah - political enemies, Khripunov "kills"/transforms the faces created by the God. He enabled himself with the right to control his patient's smiling:

«...Ей больше нельзя ульббаться, она не имеет на это права, никто не имеет на это права. Только я» (316).

A narcissistic self-position determines everything. Khripunov, like in-Sabbah in the history, determines the fate of others. This 
might be seen from the fact that a real beauty is in the surgeon's hands and he feels himself as a "creator":

«Когда операчия закончится, и оставленные им раны стиснут идеально ровные pты, в мире станет чуть-чуть больше прекрасного. На одну каплю. Но когда-нибудь Хрипунов не сомневается - он соберет эти капли в одно идеальное лицо. И тогда в мире снова вочарится Бог» (160).

Such position to accept one's own decisions and desire to be over the others draw out attention to the following two conceptions: narcissism conception and Nietzsche's conception of "God is Dead". Freud in his work "On Narcissism: An Introduction" of 1914 described the behavior of hysteric and neurotic men within the context of narcissism, since their disease "impacts their attitude to the world" and is, undoubtedly, linked to sexuality (the sexuality to oneself, autoerotism) (Matijašević, 2016: 18) - with which narcissism is mainly associated. Following Freud, the analysis shows, that such patients have not lost their erotic attitude to people and things, but saved it "in the sphere of their imagination, i.e. on the one hand the real objects are changed and mixed with the fiction images, on the other - they do not take any efforts to achieve their goals in the reality, i.e. to obtain these objects" (Freud, 2016). Our characters - Kripunov and ibn-Sabbah constantly live in their fantasies, and percept murders and destruction as creation and growth of their own power, since the narcissism involves "delusion of grandeur" (Freud, 2016). Only having that feeling of expansive delusion Hassanibn-Sabbah could say "Sleep easily, girls. Even Hassan-ibn-Sabbah cannot kill all the babies in the world", and Khripunov: "...your nose, unfortunately, is to be done one more time. To be honest, I am not quite satisfied with the result. Or not satisfied at all", or in the very end of the novel: "She dies earlier than will understand what has happened. And I make a new one".

According to Freud, a typical behavior in narcissism is an obsession to the object, what is "a possibility to separate the sexual energy as libido from the energy of "I-obsessions" (Freud, 2016). Generally speaking, a libido narcissism is divided onto the primary (transferring of the libido onto the "Self-I") and the secondary one (i.e. transferring of the libido onto other objects) (Matijašević, 2016: 18), which is, in turn, the most significant in "Surgeon".

By transferring their own power onto the objects (people are thought to be the objects), Khripunov and ibn-Sabbah not only kill the God, but, by expressing their claim to power, they take His position. Destroying the higher values, they nihilistically - since the nihilism represents devaluation of the higher values - put themselves on the place of the creator and power (Nietzsche, 1980). Both characters hyperbolize their status, i.e. feel themselves as "the sense and modus rebus of the values" (Nietzsche, 1980: 15).

The separateness of the characters by the time and space shows that there is a question of historical tradition. It looks like a prophesy ties them or points out the continuum of their fates:

«Хасан твердо знал, что, несмотря на видение родится дочка, а от нее еще одна, и еще, и так еще девятьсот с лишним лет пока не настанет наконец время мальчика, судьбу которого знал только Исам» (229).

The spaces and times are different, but the behavior of those "chosen" is the same. IbnSabbah lived in Alamut, a mountain fortress in Iran, whereas Arkady Khripunov lived in Feremov, a fiction town. Alamut was a heavy fortress in the 11th century, which is still can be found in geographical chart, despite that today 
we have only its ruins. Feremov, in turn, is a fiction town, created through the substitution of the letters in Efremov, a real town in the Tula Territory, the writer's birthplace. Thus, the whole life of ibn-Sabbah seems to be more real in comparison with Khripunov's one. When ibnSabbah died, this event was announced by the doctor who was near him in the last minutes of his life:

«...Глазные яблоки покойника стали мягкими, как свежий сыр, а позвоночник, напротив, стал тверже смертного ложе» (299).

On the other hand Khripunov's death is shown as being beyond the reality - we learn about it from the call by the Good Angel:

«Наконеи в трубке далеко, но отчетливо щелкнуло, и ангел, не открывая глаз, тихо доложил: "Он умер". "Ктог?” (...) "Он. Хирург”. И едва сльино прибавил: Бог» (317).

One more element of the novel's structure is important within the neomythologism perspective. The question is about the beginning of its each chapter. As we have already said, these titles serve to "God-creation" by Khripunov, but under them, the leading paragraphs are italicized and represent a list of surgical instruments:

«Искривленные режущие с тонким лезвием. Искривленные реверсивные режущие. Полукруглые режущие, суживаюшиеся к кониу. Сверхизогнутые режущие. Полукруглье режущие. Режущие, суживающиеся к кониу «грубые» в виде рыболовного крючка. Прецизионные, реверсивные режущие изогнутые. Прямые режущие. Троакарные полукруглье грубые» (7).

Thus, there is a unique rhythm of the prose and, together, a picture about the novel as a surgical one in general. The author-demure being on her position of the "creator" creates with special surgical instruments the written text, making the declarative structure of the narratological whole playing and, at the same time, shows how one can "create" a human "God" and then kill him.

1 Marina Livovna Stepnova is a contemporary Russian writer and editor. Critics are tend to put her editorial works first, since she worked in "Telokhranitel" (eng. - "Bodyguard"), a journal on safety and security" and then in "XXL", a men's magazine. Among the readers Stepnova is famous for her novels "Surgeon" (2005), "Lazarus's Woman" (2011) and "Godless Alley" (2014).

\section{References}

Akhmetova, M. (2010). Konets sveta v odnoi otdel'no vziatoi strane. Religioznye soobshhestva postsovetskoi Rossii i ikh eskhatologicheskii mif [The Apocalypses in a Certain Country. Religious Communities in the Post-Soviet Russia and Their Eschatological Myths]. Moscow: RGGU, Ob'edinennoe gumanitarnoe izdatel'stvo.

Baiburin, R. (2016). Gaidar-vsadnik, skachuschhii vperedi [Gaidar is a Rider Racing in Front]. Available at: http://www.proza.ru/2016/11/08/196 (accessed December 1, 2016)

Freud, Z. (2016). O nartsizme (K vvedeniiu v nartsissizm) [On Narcissism: An Introduction]. Available at: http://freudproject.ru/?p=577 (accessed December 1, 2016).

Kovtun, N. (2013). Sovremenniia traditsionalistskaia proza: ideologiia i mifopoietika. Uchebnoe posobie [The Modern Traditionalist Prose: Ideology and Mythopoetics. Study Guide]. Krasnoyarsk: SFU.

Matijašević, Ž. (2016). Stoljeće krhkog sebstva. Psihoanaliza, društvo, kultura. Zagreb: Disput. 
Meletinskii, E. (2005). Mif i dvadtsaty vek [The Myth and 20th Century]. Available at: http://www. ruthenia.ru/folklore/meletinskz1.htm (accessed June 13, 2016).

Mints, Z.G. (2004). O nekotorykh «neomifologicheskikh» tekstakh v tvorchestve russkih simvolistov [On some "neomythological" Texts in the Works by the Russian Symbolists], In Blok $i$ russkii simvolizm: Izbrannye trudy v $3 \mathrm{kn}$. [Blok and the Russian Symbolism: Selected works in 3 volumes]. Saint-Petersburg: Iskusstvo. Available at: http://www.rutheia.ru/papers/neomifologich.html (accessed July 20, 2016).

Neklyudov, S. Ju. (2000). Sturktura i funktsiia mifa [The Structure and Function of the Myth], In Mify i mifologiia v sovremennoi Rossii [Myths and Mythology in the Modern Russia]. Moscow: AIRO-HH. 17-38. Available at: http://philologos.narod.ru/mzth/nekludov.htm (accessed July 20, 2016).

Nietzsche, F. (1980). Volja za moć. Pokušaj prevrednovanja svih vrijednosti. Prev. A. Stamać. Zagreb: IKRO Mladost.

Nikolina, N.A. (2009). Narrativnaia struktura sovremennogo prozaicheskogo teksta [The Narrative Structure of the Modern Prosaic Text], In Dinamika formy khudozhestvennogo teksta: stikh, proza, drama v kontse XX-nachale XXI veka [The Dynamics of Form of the Literary Text: Poem, Prose and Drama in the End of the 20th - Beginning of the 21st Centuries]. Halle (Saale): Institut russkogo yazyka im. V.V. Vinogradova Rossiiskoi akademii nauk, Institut slavistiki universiteta im. M. Luther, Halle-Wittenberg.

Rudnev, V.P. (1999). Slovar' kul'tury XX veka. Kliuchevye poniatiia i teksty [The Dictionary of the 20th Century Culture. Key Notions and Texts]. Moscow: Agrafa.

Šentija, J. (ur.) (1977). Opća enciklopedija Jugoslavenskog leksikografskog zavoda. Sv. 3. Zagreb: JLZ.

Stepnova, M. (2016). Hirurg [Surgeon]. Moscow: Izdatel'stvo AST.

Solar, M. (2000). Postmodernizam i mit, In Granice znanosti o književnosti. Izabrani ogledi. Zagreb: Naklada Pavičić.

Zamarovský, V. (1989). Junaci antičkih mitova. Zagreb: Školska knjiga.

\section{(Нео)мифологические элементы}

\section{в современной русской прозе}

(на примере романа «Хирург»

\section{Марины Степновой)}

Я. Войводич

Загребский университет

Хорватия, 10000, Загреб, ул. Ивана Лучича, 3

В статье речь идет о приеме неомифологизации в романе «Хирург» Маринь Степновой. Принимая во внимание, что неомифологизм является важной составляющей в современной социокультурной ойкумене и довольно сложным понятием, мы в тексте Степновой анализировали один сегмент неомифологизации - сотворение и убивание «бога» и божественной позиции. Главный герой романа, пластический хирург Хрипунов, живущий в ХХ веке, наподобие Хасана 
ибн Саббаха, стариа Горы ХІ века, является своеобразным «богом», что в тексте читается сквозь призму нарииссизма и желания приобретения мощи. На структурном уровне демиургом выступает сам автор, организующий нарратологическое цеелое двухпланового текста.

Ключевые слова: неомифологизм, «смерть бога», наричссизм, «Хирург», Степнова.

Текст написан по проекту «Неомифологизм в культуре 20-го и 21-го веков», составленному хорватским научным фондом (Неомит, HRZZ, 6077).

Научная спеииальность: 10.00.00 - филологические науки. 